\title{
PERUBAHAN NILAI TUKAR UANG MENURUT PERSPEKTIF EKONOMI ISLAM
}

\author{
Leni Saleh \\ Dosen Program Studi Agribisnis Fakultas Pertanian Universitas Lakidende \\ E-mail: cici_raslin@yahoo.co.id
}

\begin{abstract}
Changes in the exchange rate is an important issue because the exchange rate is always changing and is not permanent. In economic theory, reduced and increased the amount of money for a person if pursued in a fair, because money can not develop with itself without any work done. In the Islamic economic system of currency exchange is still controversy in the changes resulting from the exchange rate outstanding. As well as with the existing implications of changes in the excange rate, which is an important Islamic economic discourse, so it should be in revisit the principles according to Islamic economic perspective.

Based on the results of studies describing the discussion of this literature study/library, showed that: (1) exchange rate in Islamic economics is part of a transaction that mubah or allowed. Currency exchange either from the same country as well as an other countries must meet the requirements that exist in Islamic economics, (2) the implications of changes in currency exchange rates not only impact on the level of domestic goods but also affecting the price of the currency a country, so that deflation and inflation can not be avoided. The implication of changes in the exchange rate of the most looked for our nation that the currency crisis that hit Indonesia and other countries in Asia. The economy collapsed due to changing currency values, resulting in rising prices of goods, both domestic and non domestic high, and (3) in the economic system of Islam, the concept of time value of money is not there. There is the concept of economic value of time. The future which has a value of economic, not money that has economic value. That if the time to good use, efficient and efectif, because increasing and decreasing the value of money if pursued with those efforts.
\end{abstract}

Keywords: Change, exchange rate, and Islamic economic.

A. Pendahuluan

Studi mengenai uang dan perbankan merupakan suatu cara untuk memahami pengaruh uang terhadap fungsi system ekonomi. Dalam membicarakan ekonomi pada umumnya, ekonomi Islam pada khususnya, rasanya agak janggal jika tidak memulainya dengan membicarakan "uang". Dalam kehidupan ekonomi, uang bagaikan darah dalam tubuh manusia. Oleh karenanya, uang memiliki nilai (dalam fungsinya) pada aktivitas ekonomi. Dalam setiap kegiatan ekonomi, tidak dapat dipisahkan dengan uang. Dengan demikian, kita perlu mempertahankan kelancaran arus peredaran uang, agar transaksi efisien, proses jual beli dapat berlangsung. Oleh karena itu dalam Islam, penumpukan uang dilarang 
karena dapat menutup arus peredaran (Muhammad, 2002).

Menurut Ibnu Taymiyah, uang dalam Islam adalah sebagai alat tukar dan alat ukur nilai. Jika di dalam nilai tukar uang itu berubah, maka harus disesuaikan dengan kondisi yang telah ada. Melalui perubahan nilai tukar itulah, nilai suatu barang akan diketahui (Karim, 2001). Disisi lain, AlGhazali menyatakan bahwa uang bagaikan kaca, kaca tidak memiliki warna tetapi dapat merefleksikan semua warna, uang tidak memiliki harga tetapi uang dapat merefleksikan semua harga. Melihat fungsi uang tersebut, menunjukkan bahwa dalam Islam adanya uang dapat memberikan fungsi kegunaan/kepuasan kepada pemakainya. Uang bukanlah komoditas, uang itu sendiri tidak memberikan kegunaan, akan tetapi fungsi uanglah yang memberikan kegunaan.

Dengan demikian, secara definitif dapat diajukan bahwa fungsi uang adalah sebagai (1) media pertukaran; (2) jaga-jaga (investasi) ; satuan hitung untuk pembayaran. Uang tidak akan bernilai jika tidak digunakan sebagai alat pembayaran, maka uang yang ditumpuk tidak sama dengan uang beredar. Oleh karena itu, penumpukan uang dilarang, sebab dapat menghalangi proses atau kelancaran proses jual beli produk-produk dipasaran. Akibatnya, dapat merintangi efisiensi usaha dan pertukaran komoditas produksi dalam perekonomian (Muhammad, 2002).

Berkenaan dengan uang, dalam ekonomi konvensional, timbul pemikiran nilai uang menurut waktu (time value of money). Konsep time value of money muncul karena adanya anggapan uang disamakan dengan barang yang hidup. Dalam konsep ekonomi Islam tidak dikenal konsep time value of money, namun dalam ekonomi Islam mengenal economic value of time, yang artinya bahwa yang bernilai adalah waktu itu sendiri. Jika waktu digunakan secara efektif dan efisien, maka akan semakin tinggi nilai waktunya. Dengan demikian, uang itu sendiri sebenarnya tidak memiliki nilai waktu, tetapi waktulah yang memiliki nilai ekonomi. Dengan catatan waktu tersebut memang dimanfaatkan dengan baik.

Perbedaan sistem ekonomi yang berlaku, akan memiliki pandangan yang berbeda tentang uang dan perubahan nilai tukar uang Oleh karena itu, perubahan nilai tukar uang dalam Islam dapat dibenarkan jika dalam prosesnya (pertukarannya) tersebut tidak mengandung unsur riba tau bunga. Dalam hal ini, pertukaran mata uang bisa terjadi jika uang tersebut jelas, kontan dan bukan dengan cara kredit. Jika hal itu dapat dipenuhi, maka dapat dibenarkan sepanjang hal tersebut tidak mengandung unsur riba atau bunga (An-Nabhani, 1999).

Dalam sistem perekonomian kapitalis, uang tidak hanya dipandang sebagai alat tukar yang sah (legal tender) melainkan juga dipandang sebagai komoditas. Dengan demikian, uang dapat diperjualbelikan dengan kelebihan, baik on the spot maupun secara tangguh. Dalam perspektif ini, uang juga dapat disewakan (kasing). Berkenaan dengan uang, dalam ekonomi konvensional timbul pemikiran nilai uang menurut waktu (time value of money). Konsep time value of money muncul karena adanya anggapan uang disamakan dengan benda hidup. Hal ini berarti nilai waktu dari uang bisa bertambah dan berkurang akibat 
perjalanan waktu, walaupun tanpa disebabkan oleh upaya-upaya. Sebagai perbandingan dengan teori ekonomi konvensional, Islam membicarakan uang sebagai sarana penukar dan penyimpan nilai, tetapi uang bukanlah barang dagangan. Uang menjadi berguna jika ditukar dengan benda yang nyata atau jika digunakan untuk membeli jasa. Karena itu, uang tidak bisa dijual atau dibeli secara kredit, untuk itu perlu dipahami kebijakan Rasulullah Saw, bahwa tidak hanya mengumumkan bunga atas pinjaman sebagai sesuatu yang tidak sah tetapi juga melarang pertukaran uang dan beberapa benda bernilai lainnya untuk pertukaran yang tidak sama jumlahnya, serta menunda pembayaran jika barang dagangan atau mata uangnya adalah sama. Efeknya adalah mencegah bunga uang yang masuk ke sistem ekonomi melalui cara yang tidak diketahui (Muhammad, 2002).

Teori time value of money tidak ada dalam ekonomi Islam. Di dalam ilmu ekonomi dapat muncul risk return profile. Dengan demikian, bertambah dan berkurangnya jumlah uang bagi seseorang jika diupayakan secara wajar adalah sesuatu yang normal. Uang itu sendiri sebenarnya tidak memiliki nilai waktu, namun waktulah yang memiliki nilai ekonomi. Dengan catatan bahwa waktu tersebut dimanfaatkan dengan baik. Sehingga di dalam Islam yang ada hanyalah economic value of time bukan time value of money.

Berdasarkan uraian pada latar belakang di atas, maka tujuan dalam kajian penelitian ini dapat dirumuskan untuk: (l) Mengetahui bagaimana nilai tukar uang dalam ekonomi Islam? (2) Mengetahui bagaimana Implikasi Terjadinya Perubahan Nilai Tukar
Menurut Ekonomi Islam. (3) Mengetahui Pandangan Sistem Ekonomi Islam Terhadap Konsep Time Value Of Money

\section{B. Nilai Tukar Uang Dalam Ekonomi Islam}

\section{Pengertian dan Ruang Lingkup} Nilai Tukar

Nilai tukar adalah banyaknya barang atau jasa yang dapat ditukar atau dibeli dengan kesatuan dan pecahan uang (Hasibuan, 2001). Nilai tukar dapat dibedakan menjadi dua yaitu:

a. Nilai tukar nominal, dimana nilai tukar nominal menunjukkan harga relatif mata uang dari dua Negara. Nilai tukar nominal dinyatakan dalam kurs yang tetap, pemerintah dalam hal ini bank sentral menetapkan harga valuta asing (valas) dan tetap bersedia membeli dan menjual valas pada harga ini. Jika terjadi permintaan pada salah satu mata uang, maka pemerintah akan langsung melakukan intervensi dengan cara menambah penawaran dari mata uang yang permintaannya meningkat sehinggga keseimbangan tetap terpelihara atau pemerintah secara resmi mengubah nilai tukar lama menjadi nilai tukar baru. Perubahan nilai tukar ini dikatakan sebagai devaluasi (jika suatu mata uang resmi diturunkan) atau revaluasi (jika nilai tukar suatu mata uang resmi dinaikkan).

b. Nilai tukar riil (Er), nilai tukar riil menunjukkan tingkat ukuran (rate) suatu barang dapat diperdagangkan antar Negara. 
Nilai tukar riil ini dikenal juga sebagai nisbah perdagangan (term of rate). Jika nilai tukar riil tinggi, artinya harga produk luar relatif murah dan harga produk domestik relatif mahal. Jika nilai tukar riil turun berarti harga produk domestik akan turun sehingga meningkatkan net ekspor. Kebijaksanaan ekonomi dapat mempengaruhi nilai tukar riil. Jika pemerintah mengalami anggaran defisit maka tabungan domestik menurun. Pengaruh perubahan ini menunjukkan penawaran rupiah menjadi berkurang sehingga nilai rupiah menjadi naik (move valuable) nilai tukar riil akan mengalami kenaikan. Karena nilai rupiah meningkat maka harga barang domestik relatif menjadi lebih mahal dibandingkan harga barang luar, selanjutnya nilai ekspor akan menurun dan atau nilai import akan meningkat sehingga net ekspor akan mengalami defisit (Said Kelana dan lain-lain, 2001).

\section{Pengertian dan Ruang Lingkup Ekonomi Islam}

Ekonomi Islam adalah sekumpulan dasar-dasar ekonomi yang berdasarkan Al-Quran dan Sunnah yang merupakan bagian perekonomian yang didirikan di atas landasan dasar-dasar tersebut sesuai dengan lingkungan dan masa (Lubis, 1999). Dalam ekonomi Islam, berbagai jenis sumber daya dipandang sebagai pemberian atau titipan Tuhan kepada manusia. Manusia harus memanfaatkan seefisien dan seoptimal mungkin dalam produksi guna memenuhi kesejahteraan bersama yaitu untuk dirinya sendiri dan untuk orang lain.

Islam mengakui kepemilikan pribadi dalam batas-batas tertentu, termasuk kepemilikan alat produksi dan faktor produksi. Kekuatan penggerak utama ekonomi Islam adalah kerjasama seorang muslim, apakah ia seorang pembeli, penjual, penerima upah, pembuat keuntungan dan sebagainya, harus berpegang pada tuntutan Allah SWT dalam Alqur'an QS An-Nisa'(4) : 29 ; "Hai orang-orang yang beriman, janganlah kamu memakan harta sesamamu dengan jalan bathil, kecuali dengan perdagangan yang dilakukan secara suka sama suka diantara kalian..." (Depag RI, 1971).

Sistem ekonomi Islam menolak terjadinya akumulasi kekayaan yang dikuasai oleh beberapa orang saja. Islam juga melarang setiap pembayaran bunga (riba) atas berbagai bentuk dan juga melarang menimbun harta kekayaan baik berupa uang maupun barang karena hal tersebut membuat roda perekonomian terhenti. Seorang muslim yang kekayaannya melebihi ukuran tertentu diwajibkan membayar zakat. Dengan demikian, tujuan ekonomi Islam untuk kesejahteraan bersama akan tercapai.

3. Perubahan Nilai Tukar dalam Perspektif Ekonomi Islam Istilah nilai tukar biasa disebut kurs. Kurs adalah perbandingan nilai tukar uang suatu Negara dengan mata uang Negara asing atau perbandingan nilai tukar valuta antar Negara. Pengukuran nilai atau nilai tukar dipengaruhi oleh besarnya volume perdagangan Negara tersebut. Pengukuran nilai 
kurs ini secara umum dipengaruhi oleh perubahan tingkat harga yang berlaku pada suatu negara dibandingkan perubahan tingkat harga pada Negara partnernya. Nilai kurs semacam ini dikenal sebagai kurs efektif. Kurs atau nilai tukar adalah sesuatu yang penting karena:

a. Perdagangan internasional (ekspor impor) dapat dilakukan.

b. Pembayaran transaksi komersial dan finansial antar negara dapat terlaksana.

c. Kerjasama lalu lintas pembayaran (LLP) antar bank devisa dunia dapat terlaksana.

d. Transaksi jual beli valuta asing (valas) dapat dilakukan.

e. Orang dapat bepergian antar Negara (Hasibuan, 2001).

Dalam ekonomi Islam, aktivitas pertukaran mata uang atau kurs disebut aktivitas sharf. Dimana aktivitas sharf tersebut hukumnya mubah. Sharf adalah jual beli atau pertukaran antara satu mata uang asing dengan mata uang asing lain, seperti rupiah dengan dolar, dolar dengan yen dan sebagainya (Arifin, 2003).

Menurut An-Nabhani dalam bukunya yang berjudul membangun sistem ekonomi alternatif perspektif Islam, apabila aktivitas pertukaran tersebut sempurna, kemudian salah seorang diantara mereka ingin menarik kembali, maka tindakan semacam ini tidak diperbolehkan bila akad dan penyerahannya sudah sempurna. Kecuali disana terjadi penipuan yang keji (ghabu fasihy), atau cacat maka boleh.

Nilai tukar kurs dapat berubah dari waktu ke waktu sebagai akibat perubahan nilai atau dinamakan perubahan harga relatif (merujuk pada inflasi berarti harga nominal atau perubahan dari seluruh harga, sedangkan perubahan harga relatif tidak semua harga barang berubah). Dalam hal ini berada pada tingkat harga yang naik cepat, naik lebih lambat bahkan ada yang turun. Ilustrasi kurs dapat berubah karena perubahan harga relatif. Jadi dapat dikatakan perubahan tingkat harga maupun kurs dipengaruhi oleh banyak faktor.

Dari uraian diatas, maka perubahan nilai tukar uang dalam ekonomi Islam hukumnya mubah atau boleh dengan syarat:

a. Pada sistem kurs tetap, perubahan nilai tukar uang, bank sentral harus menetapkan harga valuta asing (valas) dan menyediakan atau tetap bersedia membeli dan menjual valas dengan harga yang telah disepakati bersama. Jika terjadi perubahan permintaan pada salah satu mata uang, maka pemerintah (dalam hal ini bank sentral) agar segera melakukan intervensi dengan cara menambah penawaran dari satu mata uang yang permintaannya meningkat sehingga keseimbangan dapat tetap terpelihara.

b. Pada sistem kurs fleksibel atau sistem kurs mengambang, pemerintah tetap mengawasi jalannya mekanisme perubahan nilai tukar tersebut sehingga spekulasi atau permainan nilai mata uang tidak terjadi atau dibiarkan bebas. Sehingga kurs tidak melonjak drastis akibat tidak adanya intervensi pemerintah. 
c. Dalam pertukaran mata uang atau kurs, harus memenuhi syaratsyarat yang telah ditetapkan sebagaimana hadist atau dalil kebolehan pertukaran tersebut adalah: "Juallah emas dengan dengan perak sesuka kalian, dengan (syarat harus) kontan". (Hr. Imam At-Tirmidzi, dari Ubadah bin Shamit).

Dari dalil tersebut, maka syarat-syarat dari nilai tukar uang atau kurs antara lain :

1) Harus tunai, tidak dengan cara kredit.

2) Serah terima harus dilaksanakan dalam majelis kontak.

3) Bila dipertukarkan mata uang yang sama harus dalam jumlah/kuantitas yang sama. Tapi jika dalam pertukaran antara dua jenis mata uang hanya diisyaratkan kontan dan barangnya sama-sama ada.

\section{Implikasi Terjadinya Perubahan} Nilai Tukar Menurut Ekonomi Islam

Implikasinya terjadinya perubahan nilai tukar uang bukan saja berdampak pada tingkat barang domestik tetapi juga berdampak pada tingkat harga dari mata uang suatu negara. Jika pemerintah mengalami anggaran defisit maka tabungan domestik menurun. Pengaruh perubahan ini menunjukkan penawaran rupiah menjadi berkurang sehingga nilai rupiah menjadi naik (more valuable) nilai tukar riil akan mengalami kenaikan. Karena nilai rupiah meningkat maka harga barang domestik relatif menjadi mahal dibandingkan harga barang luar. Selanjutnya nilai ekspor akan menurun dan atau nilai impor akan meningkat sehingga net ekspor akan mengalami deficit (Arifin, 2003). Jika pihak luar negeri melakukan anggaran defisit, maka hal ini akan menaikkan tingkat bunga dunia selanjutnya akan menurunkan investasi sehinggga terjadi kenaikan penawaran rupiah yang tersedia yang dapat ditawarkan untuk diinvestasikan keluar negeri. Banyaknya rupiah akan menurunkan nilai tukar riil, menjadikan rupiah kurang berharga dan selanjutnya harga barang domestik akan relative lebih murah dibandingkan harga barang luar negeri, ekspor akan meningkat dan atau impor akan turun dan net ekspor akan surplus.

$$
\text { Implikasi terjadinya }
$$

perubahan nilai tukar uang menurut ekonomi Islam dapat dikategorikan menjadi dua bagian ;

a. Dengan adanya pertukaran mata uang yang dimana dalam nilai tukar uang atau kurs yang dinamakan kurs fleksibel atau mengambang tanpa pengawasan pemerintah, dalam hal ini bank sentral, maka dalam transaksi terjadi transaksi finansial. Dalam istilah finansial, games of chance yang dilakukan dengan perkiraan yang rasional dan intelijen disebut spekulasi. Dimana dalam games of chance dapat diupayakan kemenangannya dengan strategi dan taktik. Dengan spekulasi benar-benar membuat sektor finansial bergerak liar tanpa kontrol sehingga dengan kemampuan ini, seorang spekulator dapat menguasai aset, 
saham bahkan pasar. Dan hal ini menjadikan banyak korban transaksi sejenis. Apalagi dalam sistem kurs yang bergerak sesuai mekanisme pasar, maka tingkat spekulasi akan semakin liar tanpa adanya kontrol dari pemerintah yang menentukan tingkat perubahan nilai tukar mata uang yang terjadi

b. Adanya spekulasi dalam pasar valas. Dalam hal ini adalah transaksi margin trading yang merupakan transaksi jual beli valas tanpa pergerakan dana, dengan menggunakan sejumlah dana (cash margin) dalam persentase tertentu (misalkan 10\%) sebagai jaminan. Dengan transaksi ini, dalam sehari bank dapat melakukan transaksi berulang-beulang. Adapun penyelesaian pembayaran dan perhitungan untung ruginya dilakukan secara netto saja. Jadi jual beli valas yang dilakukan bukan untuk memilikinya, melainkan semata-mata untuk spekulasi. Transaksi ini sangat ditentukan oleh faktor keberuntungan yang dalam istilah finansial disebut faktor eksternal. Transaksi ini sangat berbahaya bagi perekonomian dan perdagangan. Hal tersebut dapat terjadi akibat ulah para spekulan, maka harga naik dan hal tersebut sangat merugikan masyarakat.

Implikasi terjadinya nilai tukar uang menurut Said Kelana adalah dengan melihat hubungan antara nilai tukar nominal dan nilai tukar riil. Dengan demikian dapat dikatakan bahwa persentase perubahan nilai tukar nominal sama dengan persentase perubahan nilai tukar riil ditambah dengan perbedaan inflasi antara inflasi luar negeri dan inflasi domestik (persentase harga inflasi). Jadi tingginya inflasi akan menurunkan nilai tukar nominal. Jadi dengan menaikkan penawaran uang maka akan menaikkan harga barang yang diukur dengan uang (term of money) sekaligus akan menaikkan valas yang diukur dengan mata uang domestik.

Dengan menggunakan data "first difference ", Said Kelana menemukan bahwa faktor perbedaan pasokan uang (money supply) dan faktor perbedaan indeks harga memberikan kontribusi besar dan signifikan terhadap perubahan nilai tukar. Faktor perbedaan tingkat bunga memberikan kontribusi yang kecil tapi signifikan sedangkan faktor cadangan devisa dan net ekspor memberikan kontribusi yang kecil dan signifikan. Implikasi perubahan nilai tukar uang yang paling nampak bagi bangsa kita saat terjadinya krisis mata uang yang melanda Indonesia beberapa tahun yang lalu dan sejumlah negara asia.

\section{Pandangan Sistem Ekonomi Islam Terhadap Konsep Time Value of Money}

1. Teori Sistem Ekonomi Islam dalam Nilai Tukar Uang

Teori ekonomi Islam sebenarnya bukan ilmu baru dari teori ekonomi yang ada sekarang. Sistem ekonomi Islam membolehkan prinsip-prinsip dan hukum ekonomi modern yang ada tidak bertentangan dengan yang dilarang dalam Islam. Dalam Islam, ilmu ekonomi dan sistem ekonomi masing-masing 
membahas tentang ekonomi, akan tetapi ilmu ekonomi dan sistem ekonomi adalah hal yang berbeda sama sekali. Dimana antara konsep yang satu dengan konsep yang lainnya tentu tidak sama. Sistem ekonomi tidak dibedakan berdasarkan banyak dan sedikitnya kekayaan, bahkan sama sekali tidak berpengaruh oleh kekayaan sebab banyak dan sedikitnya kekayaan tersebut dari sisi manapun tidak mempengaruhi bentuk sistem ekonomi.

Dengan demikian, teori sistem ekonomi Islam dalam nilai tukar sangat erat dengan faktor kebutuhan. Dimana yang mendorong orang untuk melakukan pertukaran mata uang adalah adanya kebutuhan salah seorang dari dua penukar pada mata uang yang menjadi milik penukar lain. Teori sistem ekonomi Islam dalam nilai tukar uang diwujudkan dalam mekanisme bagi hasil dan jual belikan peredaran modal yang sebebas-bebasnya membuat perekonomian suatu negara satu demi satu akan rusak dan kredit macet menjadi gejala global. Bagaimana tidak, pasar uang yang telah berkembang begitu cepat sehingga terlepas dari pasar barang dan jasa.

Dari uraian di atas jelas bahwa teori ekonomi Islam dalam nilai tukar uang yaitu sebagai berikut :

a. Dalam nilai tukar uang, baik di lakukan dalam satu negara ataupun antar negara, wujud transaksi itu harus jelas, kontan, ada pada saat dilaksanakan transaksi, dan jenis serta kuantitasnya harus sama (jika dilakukan dalam satu negara yang mata uang sama atau negara yang mata uangnya berdasar emas dan perak).

b. Uang bukan komoditas, praktek penggandaan uang dan spekulasi dilarang, sehingga bentuk-bentuk transaksi maya dapat dihindarkan. Dalam sistem ekonomi Islam, segala bentuk transaksi maya dilarang, karena pasar uang akan tumbuh jauh lebih cepat daripada pertumbuhan pasar barang dan jasa. pertumbuhan yang tidak seimbang akan menjadi sumber krisis seperti terjadi sekarang. Pelarangan riba pada hakikatnya merupakan pelanggaran transaksi maya. Sebagaimana firman Allah SWT dalam QS. Ar-Ruum : 39 yang artinya sebagai berikut: "Dan sesuatu riba (tambahan) yang kami berikan agar dia bertambah pada harta manusia, maka riba itu tidak menambah pada sisi Allah. Dan apa yang kamu berikan berupa zakat yang kamu maksudkan untuk mencapai keridhaan Allah, maka (yang berbuat demikian) itulah orangorang yang melipat gandakan (pahalanya).

\section{Konsep Time Value Of Money dalam Nilai Tukar Uang}

Konsep time value of money pada dasarnya merupakan intervensi konsep biologi dalam ekonomi. Konsep time value of money muncul karena adanya anggapan uang disamakan dengan barang hidup (sel hidup). Sel yang hidup untuk satuan waktu tertentu dapat menjadi besar dan berkembang. Pertumbuhan sel 
dalam ilmu biologi diformulasikan dengan rumus sebagai berikut:

$$
\mathrm{Pb}=\mathrm{P}_{0}(1+\mathrm{g})^{\mathrm{t}}
$$

Keterangan :

$\mathrm{Pb}=$ Pertumbuhan sel

$\mathrm{P}_{0}=$ Sel pada awalnya

$\mathrm{g}=$ Pertumbuhan

$\mathrm{t}=$ Waktu

Formula ini diadopsi kemudian dalam ilmu keuangan akibatnya, anggapan uang sebagai sesuatu yang hidup terjadi. Dari formula tersebut akhirnya dirumuskan sebagai berikut :

$$
F v=P v(1+i)^{n}
$$

Keterangan :

$\mathrm{Fv}=$ Future value (nilai uang masa yang akan datang)

$\mathrm{Pv}=$ Present value (nilai uang masa sekarang)

$\mathrm{i}=$ tingkat suku bunga

$\mathrm{n}$ = waktu (Muhammad, 2002).

Dalam ilmu ekonomi

konvensional uang dipandang sebagai sesuatu yang sangat berharga dan dapat berkembang dalam suatu waktu tertentu. Anggapan demikian melahirkan time value of money. Time value money adalah nilai, waktu dari uang yang bisa bertambah dan berkurang sebagai akibat perjalanan waktu (Damodaran, 2001). Dengan demikian, memegang uang orang dihadapkan pada risiko menurunnya daya beli dari kekayaannya sebagai akibat dari inflasi sedangkan dengan memilih menyimpan uang dalam bentuk surat berharga, pemilik memperoleh bunga yang diperkirakan di atas inflasi yang terjadi. Dengan demikian, nilai uang saat sekarang nilai subsitusinya terhadap barang akan lebih tinggi dibanding nilainya di masa yang akan datang.
Lebih jelasnya, konsep time value of money diwujudkan dalam bentuk tingkat bunga. Tingkat bunga dianggap sebagai harga dari komoditas uang. Perdagangan surat berharga di pasar uang antara bank dan produk-produk perbankan lainnya, sebenarnya pada hakikatnya menjadi perdagangan komoditas uang, menjual surat berharga dapat diartikan memakan uang masa kini dan uang masa dimasa depan yang jumlahnya tidak sama.

Dalam teori ini, Bunga merupakan pengganti value perbedaan nilai (dari nilai sekarang atau present value dan nilai yang akan datang atau future value). Bunga adalah besarnya penggantian perbedaan antara nilai sekarang dengan nilai yang akan datang. Konsep time value of money atau yang disebut dalam ekonomi sebagai positif time preference menyebutkan bahwa nilai komoditi pada saat ini lebih tinggi dibandingkan nilainya dimasa depan (Achsien, 2003).

Dari uraian di atas, konsep time value of money dalam nilai tukar uang sangat mempengaruhi tingkat nilai tukar. Apalagi dalam ekonomi konvensional mendefenisikan nilainilai, menurut mereka adalah nilai menurut anggapan atau spekulaasi, dimana nilai bisa berubah menjadi harga, apalagi sesuatu yang dipergunakan dijadikan sebagai standar atau ukuran. Jadi nilai bersifat nisbi (relatif). Maka seorang spekulan harus professional, ekstra hati-hati dan terus-terus memantau nilai kurs atau nilai tukar antar valas yang berlaku di dunia agar apa yang 
diusahakan terus dapat memperoleh keuntungan.

3. Time Value of Money Menurut Perspektif Ekonomi Islam

Di dalam ekonomi Islam, konsep time value of money tentunya tidak akan terjadi. Di dalam Islam, keuntungan bukan saja keuntungan di dunia namun yang dicari adalah keuntungan di dunia dan di akhirat. Karena itu, pemanfaatan waktu bukan saja harus efektif dan efisien. Namun juga harus didasari dengan keimanan. Keimanan inilah yang mendatangkan keuntungan di akhirat. Sebaliknya, keimanan yang tidak mampu mendatangkan keuntungan di dunia, berarti keimanan tersebut tidak diamalkan. Islam mengajarkan keuntungan akhirat tetapi jangan lupakan keuntungan dunia.

Dalam dunia bisnis, ajaran $\mathrm{Al}$ qur'an tersebut mengindikasikan bahwa dalam bisnis selalu dihadapkan pada untung dan rugi. Keuntungan dan kerugian tidak dapat dipastikan untuk masa yang akan datang. Bisnis bukanlah aktivitas yang mendatangkan keuntungan tanpa ada risiko. Sebagaimana dijelaskan pada konsep time value of money, bahwa sebagai pengganti atas situasi ketidakpastian, maka dimunculkan konsep discount rate (Karim, 2003).

Menurut pandangan ekonomi Islam, penggunaan sejenis discount rate dalam menentukan harga mu'ajjal (bayar tangguh) dapat dibayarkan. Hal tersebut dapat dibenarkan karena:

a. Jual beli dan sewa menyewa adalah sektor riil yang menimbulkan economic value added (nilai tambah ekonomis).

b. Tertahannya hak si penjual (uang pembangunan) yang telah melaksanakan kewajibannya menyerahkan barang dan jasa), sehingga ia tidak dapat melaksanakan kewajibannya kepada pihak lain. Dengan kata lain, selain itu ada beberapa asumsi dan kejadian yang dapat dijadikan rujukan analisisnya yaitu :

1) Harga yang dibayar tangguh dapat lebih besar daripada harga yang dibayar sekarang

2) Not due to inflation nor interest fore gone

3) Adanya penahanan hak si pemilik barang.

Asumsi ini merujuk pada apa yang pernah dilakukan oleh Zaid Bin Ali Zainal Abidin Bin Husein Bin Ali Thalib. Demikian pula penggunaan discount rate dalam menentukan nisbah bagi hasil, juga dapat digunakan nisbah yang dikalikan dengan pendapatan aktual, bukan dengan pendapatan yang diharapkan. Transaksi bagi hasil berbeda dengan transaksi jual beli atau sewa menyewa sebab dalam transaksi bagi hasil, hubungan antara kedua belah pihak, tidak terjadi antara penjual dan pembeli atau penyewa dengan yang menyewakan.Dalam transaksi bagi hasil hubungan yang terjadi adalah hubungan pemodal dengan yang memproduksikan modal tersebut.Hak mereka adalah berbagi hasil atau pendapatan atau keuntungan tersebut, sesuai kesepakatan awal. Dengan demikian, uang itu sendiri sebenarnya tidak 
memiliki nilai waktu. Namun waktulah yang memiliki nilai ekonomi. Dengan catatan bahwa tersebut memang dimanfaatkan secara baik. Dengan adanya nilai waktu tersebut, maka kemudian dapat diukur dengan batasanbatasan ekonomi.

Di dalam ekonomi Islam, tidak dikenal adanya money demand for speculation.Sebab spekulasi tidak dibolehkan dan kebalikan dari sistem ekonomi konvensional, yang memberikan bunga pada harta. Dalam Islam, harta adalah sesuatu yang dikenai zakat jika disimpan telah mencapai haulnya. Karenanya, motif money for transaction serta money demand for precountionary dikenal dalam ekonomi Islam. Karena itu konsep time value of money tidak ada dalam ekonomi Islam tetapi yang ada adalah economic value of time. Berdasarkan uraian diatas, maka mekanisme menurut ekonomi Islam tentang persoalan nilai waktu uang yang diformulasikan dalam bentuk bunga adalah tidak dapat diterima.Dengan demikian, perlu dipikirkan bagaimana formula pengganti seiring dengan nilai dan jiwa Islam. Hubungan formula tersebut dapat ditemukan formula investasi menurut pandangan Islam sabagai berikut :

Keterangan :

$$
\mathrm{Y}=(\mathrm{QR}) \mathrm{v}^{\mathrm{w}}
$$

$\mathrm{Y}=$ Pendapatan

$\mathrm{Q}=$ Nisbah bagi hasil

$\mathrm{V}=$ Tingkat pemanfaatan harta

$\mathrm{w}=$ Harta yang ditabung

Formulasi ini, dapat diterapkan sebagai pengganti formula time value of money karena formula ini tidak menggunakan mekanisme bunga. Akan tetapi, menggunakan dasar mekanisme bagi hasil dan return usaha yang terjadi secara riil. Dengan formula tersebut, yang memberikan nilai ekonomi adalah pemanfaatan waktu yang ada, sehingga di dalam ekonomi Islam yang ada hanyalah economic value of time bukan time value of money (Muhammad, 2002).

\section{Kesimpulan}

Dari uraian di atas dapat disimpulkan sebagai berikut:

1. Nilai tukar uang dalam ekonomi Islam merupakan bagian dari jual beli yang hukumnya mubah atau boleh. Pertukaran mata uang baik dari negara yang sama maupun antar negara harus memenuhi syaratsyarat yang ada dalam ekonomi Islam. Dimana ketentuan-ketentuan atau syarat pertukaran mata uang adalah sebagai berikut: (1) membeli dan menjual valas dengan harga yang disepakati bersama, (2) tunai, tidak dengan cara kredit, (3) barang yang dipertukarkan harus ada, jelas dan dapat dipertanggungjawabkan, (4) peran pemerintah dalam mengawasi jalannya pertukaran mata uang harus dioptimalkan.

2. Implikasi terjadinya perubahan nilai tukar uang bukan saja berdampak pada tingkat barang domestik tetapi juga berdampak pada tingkat harga dari mata uang suatu negara, sehingga terjadinya deflasi dan inflasi tidak dapat terhindarkan. Implikasi perubahan nilai tukar uang yang paling tampak bagi bangsa kita yaitu terjadinya krisis mata uang yang melanda Indonesia dan sejumlah negara Asia. Perekonomian terpuruk akibat nilai mata uang 
berubah sehingga mengakibatkan harga-harga barang naik baik domestik maupun non domestik tinggi.

3. Dalam sistem ekonomi Islam, konsep time value of money tidak ada yang ada adalah konsep economic value of time. Dimana waktulah yang memiliki nilai ekonomi, bukan uang yang memiliki nilai ekonomi. Hal tersebut jika waktu digunakan secara baik, efisien, dan efektif, karena bertambah dan berkurangnya nilai dari uang jika diupayakan dengan usaha-usaha.

\section{DAFTAR PUSTAKA}

Al-Qur'an Karim

Achsien, H. Iggi. 2003. Investasi Syari'ah di

Pasar Modal. Cet.II. Jakarta:

Penerbit PT. Gramedia Pustaka Utama

An-Nabhani, Taqyuddin. 1999. Membangun Sistem Ekonomi Alternatif Perspektif Islam. Cet.IV. Surabaya: Penerbit Risalah Gusti.

Arifin, Zainul. 2003. Dasar-dasar Manajemen Bank Syari'ah. Cet.II. Jakarta: Penerbit Alvabet.
Damodaran, Aswath. 2001. Corporate Finance: Theory and Practise, $2^{\text {nd }}$ ed. New York: Jhon Wiley and Sons.

Hasibuan, Melayu S.P. 2001. Dasar-dasar Perbankan. Cet.I. Jakarta: Penerbit PT. Bumi Aksara.

Hemalambang, Tedy, Sugiarto Brastoro, Said Kelana. 2001. Ekonomi Makro Teori Analisis dan Kebijakan. Jakarta: Penerbit PT. Gramedia Pustaka Utama.

Karim, Adi Warman. 2001. Sejarah Pemikiran Islam. Jakarta: IIIT Indonesia. 2001. Ekonomi Islam Suatu Kajian Kontemporer. Cet.II. Jakarta: Penerbit Gema Insani Press.

Kelana, Zaid. 1997. Teori Ekonomi Makro. Cet.II. Jakarta: PT. Raja Grafindo Persada.

Lubis, H. Ibrahim. 2002. Ekonomi Islam Suatu Pengantar. Jilid I. Jakarta: Penerbit Kalam Mulia.

Muhammad. 2002. Kebijakan Fiskal dan

Moneter dalam Ekonomi Islam. Edisi I. Jakarta: Penerbit Salemba Empat. 2002. Manajemen Bank Syari'ah. Yogyakarta: Penerbit UPP AMP YKPN. 